\title{
Introduction: Towards a Trans-Cultural History of Muslims in Interwar Europe
}

\author{
Bekim Agai, Umar Ryad and Mehdi Sajid
}

The study of Muslims in interwar Europe is a rising and intriguing field of research. With the exception of two edited volumes, Islam in Interwar Europe by Nathalie Clayer and Eric Germain and Transnational Islam in Interwar Europe by Götz Nordbruch and Umar Ryad, ${ }^{1}$ the history of Muslims in Europe during this period is still fragmented into various fields of study as a side aspect of other issues. Some of these works deal with Muslims in interwar Europe as part of Middle Eastern and Asian history, colonial studies or briefly as related to European migration history. ${ }^{2}$ Other historians deliver nationally focused narratives of the Muslim presence in western, central, and eastern European territories focused on specific countries, framed within a national history. ${ }^{3}$

1 Nathalie Clayer and Eric Germain (eds.), Islam in Interwar Europe (London: Hurst \& Company, 2008); Götz Nordbruch and Umar Ryad (eds.), Transnational Islam in Interwar Europe: Muslim Activists and Thinkers (New York: Palgrave, 2014).

2 See, for example, Martin Seth Kramer, Arab Awakening and Islamic Revival: The Politics of Ideas in the Middle East (New Brunswick, NJ: Transaction Publishers, 2011), 103-111; William L. Cleveland, Islam against the West: Shakib Arslan and the Campaign for Islamic Nationalism (Austin: University of Texas Press, 2014): Juliette Bessis, "Chekib Arslan et les mouvements nationalistes au Maghreb," Revue historique 526 (1978): 467-489; Stéphane A. Dudoignon, Hisao Komatsu, and Yasushi Kosugi, Intellectuals in the Modern Islamic World: Transmission, Transformation, Communication (London: Taylor \& Francis, 2006); Manuela Williams, Mussolini's Propaganda Abroad: Subversion in the Mediterranean and the Middle East, 1935-1940 (New York: Routledge, 2006); Gilbert Achcar, The Arabs and the Holocaust: The Arab-Israeli War of Narratives (London: Saqi, 2010).

3 See, for example, Alexandre Popovic, L'Islam balkanique:Les musulmans du sud-esteuropéendans la périodepost-ottomane (Wiesbaden: Harrassowitz, 1986); Alexandre Popovic, The Turks of Bulgaria (1878-1985) (Society for Central Asian Studies, 1986); Nathalie Clayer, "La Ahmadiyya lahori et la réforme de l'islam albanais dans l'entre-deux-guerres, in Véronique Bouillier \& Catherine Servan-Schreiber," De l'Arabie à l'Himalaya. Chemins croisés en hommage à Marc Gaborieau (Paris: Maisonneuve et Larose, 2004), 211-228; Humayun Ansari (ed.), The Making of the East London Mosque, 1910-1951 (Cambridge University Press, 2011); Humayun Ansari, "Between Collaboration and Resistance: Muslim Soldiers' Identities and Loyalties in the two World Wars," Arches Quarterly 4 (2011): 18-29; Humayun Ansari, “'Burying the Dead': Making Muslim Space in Britain," Historical Research 80/210 (2007): 545-566; Humayun Ansari, "The

(C) BEKIM AGAI, UMAR RYAD AND MEHDI SAJID, 2016 | DOI 10.1163/9789004301979_002

This is an open access chapter distributed under the terms of the Creative Commons

Attribution-Noncommercial 3.0 Unported (CC-BY-NC 3.0. License. 


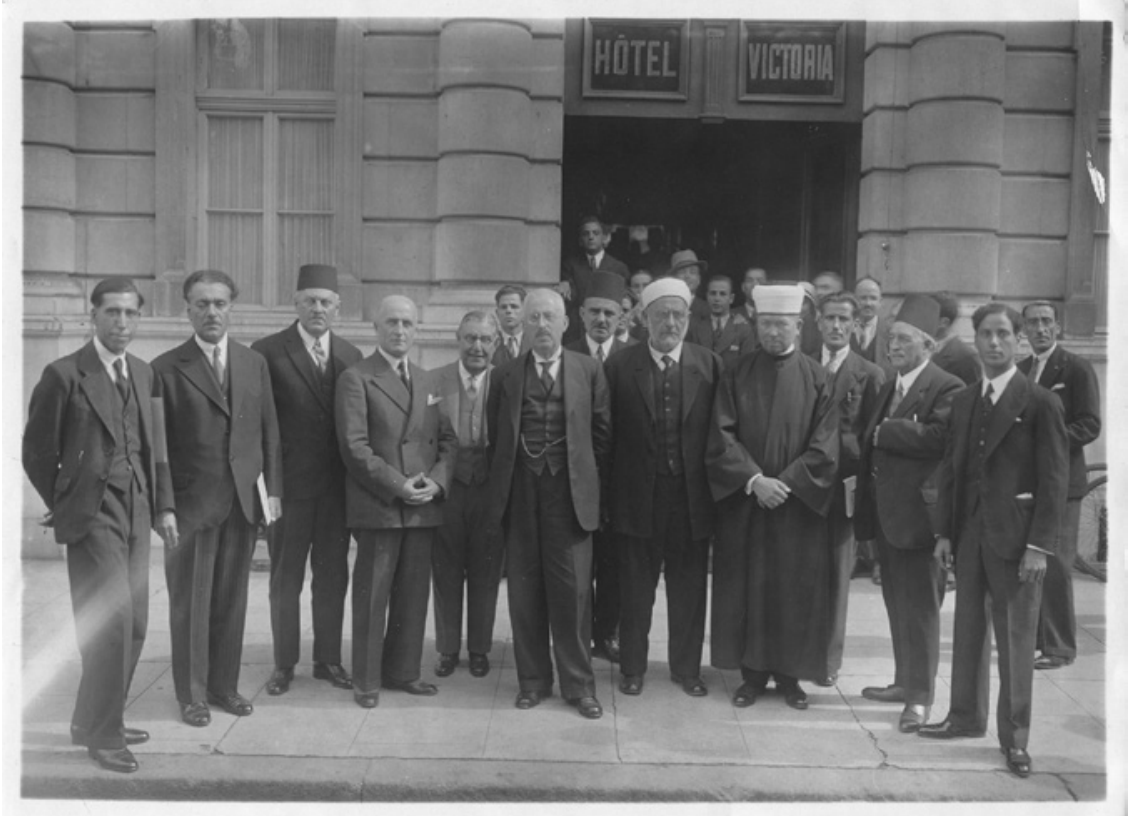

FIGURE 1.1 European Muslim Congress, 1935. Family Archive, Mohammed Alivan Beetem; Naaldwijk - The Netherlands. With gratitude to his grandson for giving access to the papers

The present volume puts the trans-cultural perspective on Muslims in interwar Europe into focus. It is the outcome of an international symposium entitled "Islam in Interwar Europe and European Cultural History," which was held at Leiden University (13-14 December 2012). It was organized by the three editors

Woking Mosque: A Case Study of Muslim Engagement with British Society since 1889," Immigrants \& Minorities 21/3 (2002), 1-24. Gerhard Höpp, Arabische und islamische Periodika in Berlin und Brandenburg 1915 bis 1945: geschichtlicher Abriss und Bibliographie (Berlin: Das Arabische Buch, 1994); Gerhard Höpp (ed.), Mufti-Papiere: Briefe, Memoranden, Reden und Aufrufe Aminal-Husainīs aus dem Exil 1940-1945 (Berlin: Schwarz, 2001); Gerhard Höpp, "Arab Inmates in German Concentration Camps until the End of World War II," in Wolfgang Schwanitz (ed.), Germany and the Middle East, 1871-1945 (Madrid u.a.: Iberoamericana, 2004); Gerhard Höpp, "Zwischen Entente und Mittelmächten: arabische Nationalisten und Panislamisten in Deutschland (1914 bis 1918)", Asien, Afrika, Lateinamerika: Zeitschrift des Zentralen Rates für Asien-, Afrika- und Lateinamerikawissenschaften in der DDR5 (1991): 827-845; Gerhard Höpp and Gerdien Jonker, In fremder Erde. Zur Geschichte und Gegenwart der islamischen Bestattung in Deutschland (Berlin: Verlag Das Arabische Buch, 1996). 
of this volume in cooperation with the Leiden University Centre for the Study of Islam and Society (LUCIS) and the research group "Europe from the Outside" at the University of Bonn sponsored by the German Federal Ministry of Education and Research (вмвғ). ${ }^{4}$ A number of scholars from various disciplines were invited to discuss how individuals and groups labeled as "Muslims" interacted with their respective European societies during the interbellum period. ${ }^{5}$ Some of the guiding questions were: What were their circumstances in their countries of residence? How did they interact as a minority group with the majority society? What impact did their connections to their counterparts in the Muslim world have on their presence and reflections in Europe? How did the attitude of their respective European societies influence their understandings of Islam and Europe? What kind of new challenges did their presence represent for the European societies? In dealing with questions of this kind the participants attempted to scrutinize some gray areas of European history and connect geographically restricted findings; this has the potential to give us a whole new perspective on the Muslim presence in interwar Europe.

The following chapters aim to fill a gap by reflecting on different examples of Muslim presences and interactions in western, central, and eastern Europe and by offering an integrative approach to include them in European history. Muslim autochthonous and émigré groups and individuals in interwar Europe are indeed difficult to categorize. The contributors try to further our understanding of Muslim social, political, intellectual, and religious activities in European history, by offering the necessary historical depth to the growing body of literature on Islam and Muslim minorities in the West. The volume thus pieces together specific case studies that emphasize the interconnections between Muslim religiosity, political activism, and modernity in interwar Europe by considering them as complex, borderless, self-organized, cross-cultural, and multi-ethnic groups. Here there is a focus on the idea of the entanglement of Muslim and European memories as "parallel histories." The volume aims to contribute to the existing debates on the historiography and territorialities of the Muslim world

4 See http://www.hum.leidenuniv.nl/godsdienstwetenschappen/nieuws/islam-in-interwar -europe-2012.html; http://media.leidenuniv.nl/legacy/r\%26b-vol3-iss4-muslims-in-interwar -europe.pdf; http://www.ioa.uni-bonn.de/abteilungen/islamwissenschaft/europe-from-the -outside/activities-and-events/international-symposium-leiden-university-netherlands -2012 (accessed 19 November 2013).

5 See the coverage of the Turkish Review (1 August 2013) to the conference: http://www .turkishreview.org/newsDetail_getNewsById.action?newsId=223353 (accessed 19 November 2013). 
by situating Muslim actors in the European context during this crucial time of global entanglements.

\section{Europe as a Transcultural Space for Muslim Action}

In recent years, historians have become interested in studying political, religious, and social movements beyond local cultural borders. In the editors' view, the focus of the present volume is innovative, as the contributions study the complexity of the Muslim presence in interwar Europe from a transcultural historical perspective. ${ }^{6}$ By studying the processes of culture transfer and border crossings of Muslim transnational actors in the interbellum period, the volume offers a more global understanding of the European past, one that goes beyond the histories of defined entities such as nations or classes. Such an approach widens our sense and scope of history by producing a more dynamic history of all those who identified themselves - or have been identified against their will—as "Muslims" within Europe and leads to a deeper reflection on their place in European and global history. Studying Muslim networks in interwar Europe from this perspective of "entanglement," and "trans-culturality" with and within Europe will, therefore, be useful in creating a global approach and a bigger picture by avoiding the numerous traps of the politics of forgetting or selective remembering beyond the historical narrative of the nation-state. The volume illustrates the historical development of Muslim border-crossing and trans-culturality by focusing on "significant contact zones, adaptation and exchange processes and moments of crossing borders in a global context" $^{\prime 7}$ in interwar Europe. An examination of the Muslim trans-cultural role in interwar Europe is useful to help us understand the transformation of Muslim identities and their imagined collective past in Europe before the nation-state.

Thus, many developments of Muslim actions in interwar Europe had global provenance, transcending national and assumed cultural boundaries. Studying these developments from a global and transcultural perspective can also be meaningful to the discussions about the histoire croisée approach, which has proved in recent years to be a challenge to the conceptual debates about how to understand "interwoven histories," and how to shed new light on histories

6 For more about this new historical approach, see Madeleine Herren, Martin Rüesch, and Christiane Sibille, Transcultural History: Theories, Methods, Sources (Berlin: Springer, 2012).

7 Herren, Rüesch, and Sibille, Transcultural History, 6. 
often already told in the much more restricted frames of national histories. ${ }^{8}$ As read against the background of this approach, the chapters in this volume should be seen as a prelude to a reconsideration of the interactions and intercrossings between European and Muslim cultural and political spheres in this crucial period. The study of Muslim actors in interwar Europe is a new "promising line of inquiry for the writing of a history of Europe," one that rethinks their position within the transcultural context. ${ }^{9}$ By focusing on Muslims and their action in this time, this history of interwar Europe can be seen as deeply interwoven with colonial subjects living in Europe, making Europe and the "Muslim" world partly overlapping spheres. The volume looks at how the Muslim presence and movements cut across national boundaries in interwar Europe, and made use of transnational ties. This consideration of Muslim "transnationalism," even by necessity and not primarily by design, is wellsuited to deepen our understanding of the transformations of Muslim identities and their imagined collective past in Europe before the formation of contemporary nation-states. The chapters that follow recount a variety of examples of Muslim engagement on the European continent in this crucial interwar time. Since such Muslim actors were active in Europe and had intensive contacts with peers across colonial lines, the focus on their activities and networks shows their significance for the history of Europe. Europe at that time was an attractive destination for Arab and Muslim students, revolutionaries, nationalist activists, political exiles, and intellectuals. Europe in this regard not only constitutes a geographical entity, but also an overarching intellectual space for Muslim actors. The latter, as is shown in the contributions, perceived interwar Europe as an "imaginary" borderless, cross-cultural, multi-ethnic and a pluri-national sphere for their political and intellectual action, a place where discussions on Islam took shape.

In that sense, Muslims in interwar Europe cannot be reduced to passive strangers of the internal European local politics and public debates. To be more specific, historians of the modern Middle East underestimate the role of interwar Muslim actors in writing a history of Islam and its relationship to modernity, whereas historians of Europe underestimate the insider's role of Muslims in intra-European developments. Some of the contributions in this volume try to present a picture of how Muslims, who belonged to various social, geographic, linguistic, intellectual, and religious backgrounds understood their shared "Islamness"; and how they impacted on the "Europeanness"

8 M. Werner and B. Zimmermann, "Beyond Comparison: histoire croisée and the Challenge of Reflexivity," History and Theory 45 (2006): 30-50.

9 Ibid., 43 . 
of those who interacted with them. In the following chapters, the contributors take into account the multiplicity of Muslim activities, religious and political institutions, and (re)interpretations of European homogeneity, civilization, and culture in the European setting. In this, the volume will definitely contribute to shaping not only a Muslim history, but a European history “à géométrie

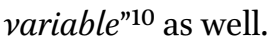

The recovery of this history of Muslims in interwar Europe, uncovered by following the trajectories of such networks, enables us to underpin the levels of interaction and fusion between local and global settings. The volume is therefore another new contribution to the different fields of European history, Islam in Europe, and Middle Eastern Studies, all coming together in the study of Islam in interwar Europe. It constitutes, on the one hand, part of the rapidly growing interest in the establishment of Islam in Europe, and on the other hand a recognition of the importance of transnational networks for the evolution of political, social, and religious movements. Thus, the use of the histoire croisée as a conceptual tool generates new concepts and shifts the scholarly focus from a study of Muslim religious/political ideals out there to see them here as part of western modernity and history. A volume like this seeks to generate "frontier knowledge" in the historical study of the Muslim pre-migration and pre-integration experience in Europe. By focusing on this field we are able to comparatively redefine the status and collective identity of Muslims in the interwar European context; their acceptance, syntheses, or rejection of influential European ideas. By studying the socio-cultural developments of Muslim activities in Europe in this formative era, we can look at the contemporary scene anew, without resorting to a neatly tailored or exaggerated hypothesis; by getting to know these first Islamic activists, we can indeed better understand the later developments of the so-called "European Islam."

\section{Muslim Activist “Frontiers" in Interwar Europe}

The interwar period was the very era in which, to a large degree, the destinies of the contemporary European and Muslim-majority societies were shaped. Contemporary Europe is indeed the result of the outcomes of this very interbellum episode, in which not only aggressive reactionary European nationalisms emerged, but also where the height of the colonial enterprise and the

\footnotetext{
10 Ibid.

11 See Ian Johnson, A Mosque in Munich:Nazis, the CIA, and the Rise of the Muslim Brotherhood in the West (Boston: Houghton Mifflin Harcourt, 2010).
} 
dichotomy between East and West was reached and culminated. In that time, Europe was not confined to its geographic borders: politics and intellectual debates in the Middle East, North Africa, and South and Southeast Asia closely followed the political modes of thinking and conflicts of the colonial centers that shaped their political and territorial realities.

Having in mind Muslim activities in the pre-World War I period, the volume traces different trajectories of Muslim activism in their new European context, in which they faced the challenges of a non-Muslim environment on them, their ideas and networks. As we shall see, being located in the metropolitan centers, Muslims in interwar Europe were in some cases able to involve themselves in both urban and overseas connections by establishing various fronts together across the European space. ${ }^{12}$ In that respect, the volume offers fascinating examples of the intersecting histories of Muslims in the international context and politics after the end of World War I. Our approach is to situate their history among other actors in Europe and reconstruct the consequences of their interaction with non-Muslims and non-Muslim institutions in terms of Muslims' experiences and self-understanding. By concentrating on Muslims living in and interacting with European societies, the central thrust of the book seeks to analyze the extent of the likely coincidence and potential interrelations of Muslim self-images and local conditions.

In their attempt to overturn France and Britain's domination of the postWorld War I international order, a number of Muslims allied themselves to anti-imperialist, leftist, Fascist, and Nazi coalitions in their anti-imperial struggles. ${ }^{13}$ However, their "counterparts" in central and eastern Europe seem to

12 See David Motadel, "The Making of Muslim Communities in Western Europe, 1914-1939," in Nordbruch and Ryad, Transnational Islam, 13-44.

13 See Peter Wien, "Coming to Terms with the Past," International Journal of Middle East Studies 42 (2010): 311-321; Peter Wien, "The Culpability of Exile: Arabs in Nazi Germany," Geschichte und Gesellschaft 37 (2011): 332-358; Götz Nordbruch, "Cultural Fusion' of Thought and Ambitions? Memory, Politics and the History of Arab-Nazi German Encounters," Middle Eastern Studies 47, no. 1 (2011): 183-194; Israel Gershoni, "Egyptian Liberalism in an Age of 'Crisis of Orientation': Al Risala's Reaction to Fascism and Nazism, 1933-39," International Journal of Middle East Studies 31 (1999): 551-576; Israel Gershoni, "Der verfolgte Jude.' Al-Hilals Reaktionen auf den Antisemitismus in Europa und Hitlers Machtergreifung," in Blind für die Geschichte? Arabische Begegnungen mit dem Nationalsozialismus, ed. Gerhard Höpp et al. (Berlin: Klaus Schwarz Verlag, 2004), 39-72; Israel Gershoni and James P. Jankowski, Confronting Fascism in Egypt: Dictatorship versus Democracy in the 1930s (Stanford, CA: Stanford University Press, 2009); Ethan Katz, 'Did the Paris Mosque Save Jews?: A Mystery and its Memory,' Jewish Quarterly Review 102, no. 2 (2012), 256-287; Raffael Scheck, 'Nazi Propaganda toward French Muslim Prisoners 
have had not only different self-representations, but also different religious and political motivations. ${ }^{14}$ As outside observers from within, Muslims in interwar Europe pushed the discussions beyond the question of anti-colonial nationalism to include the Muslim imaginations of the races, civilization, and religion in the West. While they based their claims to authenticity on Islam and its nostalgic past, they indirectly created multifaceted representations, perceptions, and narratives about Europe. By utilizing the writings and images of Europe made by Muslim exiles, we can trace the alternative views and diagnosis of the international structure of ideas and powers that Muslims offered in their attempts to find their place in the international domain.

In their new setting, Muslims in interwar Europe attempted to assert themselves as components of the emerging colonial nation-states they now belonged to on the one hand, but they had to recognize the reality and agony of colonialism in the Muslim world as such on the other. Interestingly, their presence in interwar Europe intensified their daily and constant encounters with Europe as the colonizer, which they now experienced from within. Nationalism as interpreted by Muslims adapted itself to its interwar variety of guises, causes, and transitions. These Muslim political actions took place across the boundaries of Europe and their places of origin as responses to various international political upheavals.

We should also emphasize that the relation of Muslim actors to Europe has been a longstanding crucial point of reference in contemporary debates

of War,' Holocaust and Genocide Studies 26, no. 3 (2012), 447-477. Among other works that selectively look for affinity between Islam and Nazism or Fascism, J. Herf, The Jewish Enemy: Nazi Propaganda during World War II and the Holocaust (Cambridge, MA: Harvard University Press, 2006); J. Herf, Nazi Propaganda for the Arab World (New Haven, Ст: Yale University Press, 2009); J. Herf, "Nazi Germany's Propaganda Aimed at Arabs and Muslims During World War II and the Holocaust: Old Themes, New Archival Findings," Central European History 42 (2009): 709-736; Matthias Kuentzel, Jihad and Jew-hatred: Islamism, Nazism and the Roots of 9/11 (New York: Telos Press Publishing, 2007); David G. Dalin et al., Icon of Evil: Hitler's Mufti and the Rise of Radical Islam (Transaction Publishers, 2009); K.M. Mallmann and M. Cüppers, Halbmond und Hakenkreuz: Das Dritte Reich, die Araber und Pal a stina (Darmstadt: WissenschaftlicheBuchgesellschaft, 2006).

14 See, for example, Katarzyna Górak-Sosnowska (ed.), Muslims in Poland and Eastern Europe: Widening the European Discourse on Islam (Warsaw: University of Warsaw, Faculty of Oriental Studies, 2011); Jozo Tomasevich, War and Revolution in Yugoslavia, 1941-1945: Occupation and Collaboration (Stanford, cA: Stanford University Press, 2001), 466-510; Marko Attila Hoare, The Bosnian Muslims in the Second World War: A History (London: Hurst, 2013); Emily Greble, Sarajevo, 1941-1945: Muslims, Christians, and Jews in Hitler's Europe (Ithaca, NY: Cornell University Press, 2011); David Motadel, Islam and Nazi Germany's War (Cambridge, MA: Harvard University Press, 2014). 
among Muslim intellectuals and activists. The European experience and reference is crucial for a proper "Islamic argument" in the political and intellectual debate and until today bears the legacy of this encounter. In the colonial era Muslim migrants in Europe generally developed specific insider/outsider views characterized by fascination or rejection. For Muslims in interwar Europe, local European controversies and prevailing socio-political concerns influenced their intellectual and political perceptions as well.

\section{Muslim Self-Assertion in the "Lands of the Colonizers"}

The following chapters should be read against the historical background of the legacy of Muslim reform in the late nineteenth and early twentieth century. It should be emphasized that important pan-Islamist activities took place outside the vanquished Ottoman Empire. Many Muslim actors in Europe after the end of the Great War (politicians, intellectuals, and propagandists) considered pan-Islam as the only practical way to continue their political activity. ${ }^{15} \mathrm{~A}$ number of Muslim activists in interwar Europe therefore inherited the legacy of modernist Islamic reform and pan-Islam that strove for Muslim unity across different groups and schools of thought. Their cosmopolitan experiences gave them access to ideas, and enabled them to communicate with people in order to foster their aspirations for religious reform and liberation from colonialism in the lands of the colonizers, i.e. Europe. Affected by a contemporary wave of

15 J.M. Landau, The Politics of Pan-Islam: Ideology and Organization (Oxford and New York: Oxford University Press, 1990), 228-230. See also C. Snouck Hurgronje, 'Heilige oorlog made in Germany,' De Gids 79 (1915), 1-33. For the English translation, see Joseph E. Gillet as The Holy War "Made in Germany (New York and London: G.P. Putnam's Sons, 1915). Gottfried Hagen, "German Heralds of Holy War: Orientalists and Applied Oriental Studies," Comparative Studies of South Asia, Africa and the Middle East 24, no. 2 (2004): 145-162. See also T. Luedke, Jihad Made in Germany: Ottoman and German Propaganda and Intelligence Operations in the First World War (Munster: Münster, Lit, 2005); K. Karpat, The Politicization of Islam: Reconstructing Identity, State, Faith and Community in the Late Ottoman State (Oxford and New York: Oxford University Press, 2001); D. McKale, War By Revolution: Germany and Great Britain in the Middle East in the Era of World War I (Kent and London: Kent State University Press, 1998); cf. S. McMeekin, The Berlin-Baghdad Express: The Ottoman Empire and Germany's Bid For World Power, 1898-1918 (London and New York: Belknap Press, 2010); Wolfgang G. Schwanitz, "Euro-Islam by Jihad 'Made in Germany," in Nathalie Clayer, Eric Germain (eds.), Islam in Inter-War Europe (London: Hurst \& Co. 2008), 271-301; Mustafa Aksakal, "Holy War Made in Germany’? Ottoman Origins of the 1914 Jihad," War in History 18 (April 2011): 2184-2199. 
globalization, they managed to connect themselves by cross-regional networks by which they sought to enhance their political, religious, and cultural intellectual aims. As we shall see, their political, religious, intellectual, and even military contributions were not isolated from the wider context of Europe.

In the interwar period, Muslim émigrés to Europe and indigenous European converts to Islam formed societies, congresses, and organizations in order to promote "a cosmopolitan sense of Muslim solidarity."16 The European Muslim Congress in Switzerland (1935) was the first attempt to gather Muslim activists in Europe. Its organizer, the well-known Lebanese émigré Shakīb Arslān (1869-1946) in Geneva, was a strong defender of pan-Islam, besides his panArab, anti-colonial, Islamic revivalist objectives in that time. In this congress, Arslān tried to make Geneva a center of Muslim activism, something unimaginable just one or two decades earlier; this shows the great degree to which Muslims in Europe were connected to those outside it. ${ }^{17}$ Muslim political selfassertion in interwar Europe was connected to their different ways of religious self-understanding. Because they belonged to different non-European ethnic backgrounds, their political and religious networks overlapped and even in many forms were intertwined. Besides the followers of so-called "mainstream" Islam, there were other variations of Islam, outside the mainstream, that were very active in the European public domain. The most prominent of these was the Ahmadiyya movement that operated from religious centers in London and Berlin. Their mission in Europe can in many ways be considered, in the words of Gerdien Jonker, as a Muslim "laboratory of modernity" in the European context. ${ }^{18}$ Their missionary activities in Europe were appreciated by many Muslims around the world, even if their unorthodox beliefs were highly debated. Their greatest field of success was their ability to convert indigenous Europeans to Islam; these Europeans then joined Muslim networks, published translations of Muslim texts, and explained Islam from their modern European perspective. Many of these and other converts played a significant role in the interwar period as brokers between the Muslim minorities and the majority society in Europe. Their translations of Muslim texts, their philosophical commentaries of the Islamic faith, and their self-confidence and strong sense of

16 Martin Kramer, Islam Assembled: The Advent of the Muslim Congresses (New York: Columbia University Press, 1986), 142.

17 Ibid., 142ff. For a new study on Arslān's influence on Islamic circles in Egypt from his Swiss exile, see Mehdi Sajid, Muslime in der Zwischenkriegszeit und die Dekonstruktion der Faszination vom Westen (Berlin: EB-Verlag, forthcoming).

18 Gerdien Jonker, "A Laboratory of Modernity-The Ahmadiyya Mission in Inter-war Europe," Journal of Muslims in Europe 3 (2014): 1-25. 
belonging to the European civilization made them strong allies to a variety of Muslims. Many of them left behind fascinating "conversion narratives," including statements about their choices that seemed to reflect their efforts to prove their new faith to the outside world. However, many isolated conversion stories have not been told thus far and these individual biographies must still be integrated into the larger framework of the Islamic presence in Europe. ${ }^{19}$ In general, reading their accounts of conversion reveals the complex ways in which they refashioned their spiritual orientations and melded their European lives with their Islamic identities. Their conversions to Islam included many cross-border activities that highlight significant historical aspects of connections across European and Muslim religious and cultural boundaries. In that sense, their history should not represent just the western discovery of Islam, but could also reflect the interests, perspectives, and habits of a group of people in a new religious and cultural context beyond the particular part of the world to which they belonged. Their discovery of Islam conveyed a sense of "passing" and "surpassing" that resulted from their access to western power and knowledge. 20

By consulting important primary sources, the chapters in this volume represent a significant prelude to the religious and political cultures of Islam in Europe. This can indeed shed a new light on the complexity of interactions of Muslim actors in their European contexts. By pursuing the historical antecedents and following up its culminations, this volume therefore lays a solid foundation for understanding the transitional developments and structure of various Muslim groups in the West.

19 Ali Köse, Conversion to Islam: A Study of Native British Converts (Abingdon: Routledge, 2010), 19. See John T.F. Keane, Six Months in Meccah: An Account of the Mohammedan Pilgrimage to Meccah. Recently Accomplished by an Englishman Professing Mohammedanism (London: Tinsley Brothers, 1881); Richard Burton, Personal Narrative of a Pilgrimage to el Medinah and Meccah, 2 vols. (London: G. Bell, 1913); Owen Rutter; Triumphant Pilgrimage: An English Muslim's Journey from Sarawak to Mecca, (London [etc.]: Harrap, 1937); Eric Rosenthal, From Drury Lane to Mecca: Being an Account of the Strange Life and Adventures of Hedley Churchward (also known as Mahmoud Mobarek Churchward), An English Convert to Islam (Cape Town: Howard Timmins, 1982 [repr. of 1931 edition]); H. St. John B. Philby, A Pilgrim in Arabia (London: Golden Cockerel Press, 1943); Lady Evelyn Cobbold, Pilgrimage to Mecca (London: John Murray, 1934). See also Augustus Ralli, Christians at Mecca (London: William Heinemann, 1909); A.J.B. Wavelle, A Modern Pilgrim in Mecca (London: Constable \& Company Ltd., 1913). 


\section{Contributions}

The interaction between Muslim missionaries and indigenous European converts provides a vivid example of trans-cultural entanglement. In this volume, Gerdien Jonker triggers the discussion by tracing Muslim Ahmadiyya missionary activities in interwar Berlin by focusing on German converts governed by a common quest towards new political utopias and an appetite for intellectual experiment. In the aftermath of World War I, many Germans turned their back on Christianity and went in search of spiritual alternatives. Foreign missionaries with a fresh message were welcomed, and the Weimar Republic became a stage for Hindu, Buddhist, Muslim, and alternative Christian missions. From a starting point of 1922, Jonker compares the activities of the Islamische Gemeinde Berlin and those of the Ahmadiyya Anjuman from Lahore in their German context. Jonker argues that the Muslim mission in interwar Berlin allowed for a rich transfer of knowledge, with which for one short moment the bias between East and West, periphery and center, was bridged. In order to fulfill their desire to modernize Islam, Ahmadi missionaries studied European intellectual traditions and invited Germans to attend their gatherings, which became the core of the mosque community. For their part, the Germans groped for ways to create the "future man" who would be able to solve the problems created by modernity. Jonker's contribution argues that visions of and experiments with man's progress in the name of modernity were at the heart of the missionary exchange, and he asks why converting to Islam was considered a legitimate and accepted means towards that aim. While introducing the reader to a range of convert biographies, the contribution looks for interfaces between the modernity of the missionaries and that of their recipients. The study makes clear that liberal intellectuals recognized in Islam a potential to interface with modernity, a potential that ten years later was adopted and twisted by Nazi ideologues.

Within this context of "spreading the message" in Europe, various intraMuslim disputes emerged and took sectarian shapes in their new European environments. Aspects of these sectarian conflicts were also molded by the new context and the quest of Muslims searching for a space in Europe. Some Muslims in interwar Europe, especially European converts, perceived of a universal Muslim community that should take priority above religious differences. In this respect, Umar Ryad in his contribution argues that European converts played a prominent trans-cultural role in the development of modern Islamic thought in the interwar period; they tried to bridge historically and geographically established and accepted divisions within the Muslim community, divisions which they, as newcomers, did not inherit. Whereas many of them 
maintained good relations with the Ahmadiyya missions in interwar Europe, they were also present in the debates in Salafi reformist pan-Islamic circles in Egypt. By dwelling on the materials embodied in two Muslim Salafì magazines in Egypt, al-Manār, published by Muhammad Rashīd Riḍā (1865-1935) and al-Fath, published by Rị̣ā's contemporary Syrian writer and activist Muhibb al-Dīn al-Khațib (1886-1969), Ryad emphasizes that although Salafì writers held strongly negative attitudes against the Ahmadiyya, their responses were not always homogenous. On the one hand, Muslim reformists harshly attacked Ahmadiyya doctrines, but on the other hand, in many cases they also praised their missionary work in Europe. After a short term appraisal of the Ahmadiyya success in Europe, many disputes began to emerge and finally deteriorated their relations; reaching a peak in the mid-193os. Many converts left the Ahmadiyya missions and started to establish their own organizations and societies in protest of the Ahmadiyya's refusal to recant Ghulam Ahmad's beliefs altogether. This chapter shows that although there were multiple and deeplyrooted conflicts between the Salafiyya and Ahmadiyya based on principles that could not be compromised, the presence of European converts as new engaging figures unconsciously created a certain commonality between these disagreeing Muslim branches, whose role in Europe became entwined. They all had one goal in common, namely the relevance of Islam on European soil.

Converts played a crucial role in the Islamic community in interwar Europe; and conversion took different forms. Reflecting on the role of European converts to Islam in intercultural communication and Islamic scholarship, Pieter Sjoerd van Koningsveld distinguishes between three main types of conversion: (1) permanent conversion, where the convert acts out of free will and personal conviction and therefore believes it to be a permanent step, (2) forced or fraudulent conversion, and (3) conversion of convenience, which is an insincere form of conversion performed to obtain certain interests, like marriage, access for one's children to a confessional school, access to a club or place open to adherents of a particular religion. Van Koningsveld sheds light on the controversial conversion of the Dutch orientalist Christiaan Snouck Hurgronje $\left(1857^{-1936)}\right.$ as a "semi-permanent" conversion. He argues that Snouck Hurgronje's conversion started as a temporary one, but developed into a more permanent form. After converting for a pragmatic reason, to join the pilgrimage and observe Muslim networks there, the knowledge that he remained a Muslim was restricted to a segment of Snouck Hurgronje's Muslim network, which he maintained after his journey to Mecca in the years 1884 and 1885 . Towards his European network, Snouck was crystal-clear in "defending" his conversion as merely a means to obtain access to Mecca and be accepted in a Muslim society. Van Koningsveld considers Snouck Hurgronje's conversion of 
convenience as perhaps the most successful case in colonial history of the instrumentalization of Islam for the benefit of the Islamic policies of the rulers and for the development of ethnological field studies. The key people in his Muslim network not only consolidated his social position within Muslim circles, but also enabled him to acquire his authority among Muslims, such that he acquired prestige as a Muslim religious scholar himself. He was even sometimes addressed by his Muslim interlocutors as the "Mufti of Batavia," and even as "Shaykh al-Islām fỉ al-Diyār al-Jāwiyya." Being addressed as an authority for Islam in the Netherlands and in Jawa clearly shows the supranational space in which the "Muslim world" and "Europe" could no longer be thought of as clearly distinguished units.

In his contribution, Klaas Stutje studies Indonesian students in the Netherlands during the interwar period; particularly Snouck Hurgronje's contemporaries. Although there were relatively few Muslim residents living in the Netherlands before World War II, those present succeeded in building organizations and infrastructures of their own, and are examples of early forms of Muslim self-organization in Europe. Stutje writes a Dutch chapter on the transcultural history of Islam in interwar Europe. He focuses on the Muslim association of Perkoempoelan Islam, which included the mostly Indonesian migrant communities in the Netherlands, and subsequently, the 'colonial' Muslim communities of Europe as well, as it became an inner-European actor. He also describes the attitudes of Dutch authorities towards Muslim organizations in the Netherlands at that time. By illustrating its local activities and its organizers' attempts to connect with other pan-Islamic organizations, Stutje finally concludes that the Perkoempoelan Islam was not only concerned with politics in their "home countries," but had strong roots in the Dutch environment. It was more concerned with the accommodation and representation of Indonesian workers vis-à-vis the Dutch authorities than with networking abroad. Moreover, the story of the relatively small Muslim community within the Perkoempoelan Islam is illustrative of the attitude the Dutch authorities and Dutch society at large adopted towards migrant communities in general, and of the strategies these communities adopted to cope with their inherently vulnerable position. As such this aspect of the colonial past is part of general Dutch history and shows that state interactions with Muslim organizations are not new in the Netherlands.

Other European colonial states were concerned with the situation of Muslims within their borders as well. Naomi Davidson examines the interwar origins of Muslim histories in metropolitan France as a case study. She argues that the seeds for the racialization of people identified as Muslims in France were laid during this period with the state-sponsored creation of a mosque and 
other "Muslim" sites in Paris. By examining the creation and management of these new Muslim spaces by French officials and North African religious leaders, Davidson tries to write a transnational history of Islam in Europe, one that acknowledges Islam's long presence as a fact in European social and political life. By acknowledging not only the role of French colonialism, but also that of Muslim leaders, Davidson stresses how this collaborative construction of a particular vision of Islam ultimately contributed to the process of essentialization of those people identified as "Muslim." By focusing on the Paris Mosque (Mosquée de Paris) and the Franco-Muslim Hospital (Hôpital FrancoMusulman), the author argues that this particular vision of French Islam was a blend between "Muslim" and "French" civilizations. "French Islam" inscribed Islam firmly within a French republican model, yet it simultaneously maintained Islam outside the boundaries set by French secularism. The architectural and aesthetic plans for the mosque, as well as the events that marked the milestones in its development, were essential to the creation and diffusion of a version and concept of "French Islam." In that sense, it was the panoply of interwar social and political programs that depended on the establishment of the Paris Mosque that helped establish Muslims as only and eternally Muslims in metropolitan France.

While these chapters deal with Muslim history in their religious and political realms, we should not neglect the military participation of Muslims in European wars, as this also played an important role as a pretext for the establishment of the Mosquée de Paris. This definitely contributes to our understanding of European subaltern history, a "history told from below." Ali Al Tuma offers the example of the Spanish Civil War, during which Spanish society was confronted by the presence of large numbers of Muslim Moroccan soldiers on Spanish territory. Given the history of the Reconquest campaigns against the Moors in medieval times, it was rather ironic for the Spanish Nationalists to use Muslims in a so-called Cruzada against the Spanish Republic. In addition, the use of Muslim soldiers in Spain presented the problem of how to deal with the religious differences between the Moroccan soldiers and the surrounding Spanish society. Al Tuma explains that the Spanish Nationalists dealt with this by ensuring that the Moroccan soldiers stayed within the boundaries of their religious space, even when that meant enforcing an Islamic identity. This the Nationalists did to protect the religious sensitivities of the Moroccans but also because, in Spanish eyes, the Moroccans could not be considered anything but conservative religious Muslims. The Spanish Nationalist military employed religion to justify the use of Moroccan soldiers from a Christian perspective, to attract the Moroccans to their cause with Islamic rhetoric, and to separate the Moroccans from the surrounding 
Spanish culture and society on a religious basis. This chapter sheds light on an aspect of Christian-Muslim religious relations in Europe during the interwar period and the contradictory attitudes of embracing while keeping at bay the Muslim "Other."

Besides migrant groups in western Europe, Muslims in eastern and central European territories are also part of the European past. Permanent Muslim communities, mainly prisoners of war and refugees, had already settled in the Grand Dutchy of Lithuania (then a shared monarchy with Poland) in the thirteenth and fourteenth centuries. By the end of sixteenth century, these Tatar groups had lost their language, but maintained their religion. ${ }^{21}$ In his chapter, Egdūnas Račius discusses the predicament of Muslims of interwar Lithuania as a conflicted autochthonous ethno-confessional community. He attempts to uncover the process and consequences of identity change in the Tatar Muslim community in the territory of the interwar Lithuanian nation-state, as it was captured in the formal communication between the Tatar Muslim communities and state authorities. Račius shows that the once unified Muslim community of the former Grand Duchy of Lithuania, due to new geopolitical realities, mutated into several separate, even antagonistic, national Muslim communities, which, even when given a chance after several decades, resisted reunification. The birth of new national identities among Tatars of the former Grand Duchy of Lithuania is well worth a deeper analytical look as it contributes to a wider picture of identity changes and identity building among Muslims in interwar Europe. In this regard, the Lithuanian (and arguably Polish as well as Byelorussian) Tatar case differs from the otherwise stereotypically perceived process of integration and indigenization of Muslims in Europe, then and now.

Zaur Gasimov and Wiebke Bachmann look to another aspect of the discussion; they point to Azerbaijani and Tatar discourses in interwar Europe as part of the transnational lives of those who identified themselves as Muslims in a multicultural space. After the Caucasus and Crimea were occupied by the Red Army in 1920, a number of Muslim intellectuals (both Shīì and Sunnī) from Russia left for France, Poland, and Turkey. With the financial help of the Polish authorities these émigrés founded several newspapers and journals in Paris and Warsaw with the aim of continuing anti-communist activity abroad, in yet another example of non-Muslims using Muslims for their political cause and Muslims accommodating non-Muslim actors. Islam was an important theme

21 Konrad Pędziwiatr, "The Established and Newcomers' in Islam in Poland or the Intergroup Relations within the Polish Muslim Community," in Górak-Sosnowska, Muslims in Poland and Eastern Europe: Widening the European Discourse on Islam (Warsaw: University of Warsaw, 2011), 171. 
in the Azerbaijani, Tatar, and Dagestani discourses in the interwar period, as it was percieved as a cultural legacy endangered by the communist regime. Many of the contributors to the émigré journals stressed the importance of Islam even though they were adherents of secularist and nationalist ideologies. Thus a certain ambivalence with regard to Islam can be found in these discourses. The contributors argue that while those Muslims were eager to make European readers aware of the culture and the political problems in the Soviet Caucasus and the Crimea of that time, Islam played a significant role in their argumentation when they addressed their non-Muslim public, though they tempered their discussions of it, perhaps in an attempt to avoid being perceived of as "religious Muslims." 